\author{
Jurnal KomtekInfo ( Komputer Teknologi Informasi ) \\ e-ISSN 2502-8758 || p-ISSN 2356-0010 \\ Vol : 06 || No : 01 || 2019 Hal 62-77 \\ http://Ippm.upiyptk.ac.id/ojsupi/index.php/KOMTEKINFO
}

\title{
PERANCANGAN WEBSITE PENDAFTARAN DAN PENYELEKSIAN TINGKATAN SEBAGAI MEDIA PROMOSI DI ENGLISH LANGUAGE SCHOOL PADANG
}

\author{
Agung Ramadhanu ${ }^{1,}$ Firna Yenila ${ }^{2}$, Rahmatul Husna Arsyah ${ }^{3}$, Andry Novrianto ${ }^{4}$, Jehan \\ Harka $^{5}$ \\ ${ }^{1,2,5}$ Fakultas Ilmu Komputer, Universitas Putra Indonesi "YPTK" Padang, Indonesia \\ ${ }^{3}$ Fakulltas Keguruan dan Ilmu Pendidikan, Universitas Putra Indonesi "YPTK" Padang, Indonesia \\ ${ }^{4}$ Fakulltas Ekonomi dan Bisnis, Universitas Putra Indonesi "YPTK" Padang, Indonesia \\ E-mail author : agung_ramadhanu@ upiyptk.ac.id
}

\begin{abstract}
This research describes the online registration Website, which is based on the solutions obtained from the research conducted at English Language School Padang. It was concluded that the old Information System (manual system) used is no longer relevant to the needs of the user, after the study of English Language School Padang by collecting data containing the Problems with the system manual, researchers provide solutions to the problem, by creating a Web Base System (website) that is done by doing the steps in designing the design of output inputs, and processes. The results of the analysis and the stage is applied in the application of the website that is more interactive and relevant to the needs of the user, in conducting their activities.
\end{abstract}

Key Word : Registration, Website, Web Base

\footnotetext{
Abstrak

Penelitian ini Menjelaskan tentang Website pendaftaran online, yang dibuat berdasarkan solusi yang didapat dari penelitian yang dilakukan pada English Language School Padang. Disimpulkan bahwasanya sistem informasi yang lama (manual sistem) yang digunakan tidak lagi relevan terhadap kebutuhan-kebutuhan pengguna, Setelah dilakukan penelitian pada English Language School Padang dengan cara mengumpulkan data-data yang berisikan permasalahan-permasalahan terhadap sistem yang manual, peneliti memberikan solusi terhadap masalah tersebut, dengan membuat sistem webbase (website) yang dilakukan dengan melakukan tahapan didalam merancang desain input output, dan proses. Hasil dari analisis dan tahapan tersebut diterapkan didalam aplikasi berupa website yanglebih interaktif dan relevan terhadap kebutuhan-kebutuhan pengguna, didalam melakukan aktivitasnya.
}

Kata kunci: Pendaftaran, Website, Webbase 


\section{PENDAHULUAN}

\subsection{Latar Belakang}

English Language School (ELS) adalah sebuah bidang usaha yang bergerak dalam bidang jasa penyediaan layanan tempat pembelajaran tambahan bahasa Inggris yang berada di Padang,Sumatera Barat. English Language School (ELS) menyediakan tempat pembelajaran tambahan bahasa Inggris di mulai dari anak yang berusia 5 tahun hingga karyawan perkantoran untuk tambahan pembelajran dalam berbahasa Inggris.

English Language School (ELS) mempunyai tingkatan kelas yang dapat memudahkan pengajar dalam mengajar yang sesuai dengan tingkatan nya dan dapat memudahkan pelajar menerima pembelajaran berbahasa Inggris dengan baik dan benar sesuai dengan tingkatan dan kemampuan pelajar tersebut. Selain itu lokasi tempat pembelajaran ini berada ditengah kota Padang Sumatera Barat yang dapat dengan mudah diakses.

Akan tetapi sistem yang terdapat pada English Language School (ELS) saat ini masih jauh dari kata sempurna, karena sistem yang lama masih dilakukan dengan manual yaitu dengan mengisi formulir yang hardcopy dan penyeleksian tingkatan untuk pelajar dilakukan secara manual oleh instruktur pengajar,dan proses pembayaran sehingga data dan informasi yang dihasil kan tidaklah akurat dan sering terjadi kesalahan saat pencatatan. Dengan kesalahan - kesalahan yang terjadi tentunya akan berpengaruh terhadap data pelajar yang diinputkan oleh pihak English Language School (ELS). Untuk itu perlu dibuat suatu system informasi yang baru agar nantinya dapat mempermudah pihak English Language School dalam meningkatkan pelayanan dan informasi bagi para pelajar.

\subsection{Hipotesa}

Hipotesa atau dugaan sementara yang didapat dari penelitian tersebut adalah sebagai berikut:

1. Dengan membuat aplikasi berbasis webbase diharapkan nantinya pihak English Language School (ELS) dapat memberikan pelayanan dan informasi yang cepat bagi para Pelajar yang baru mendaftar.

2. Dengan adanya sistem yang baru, diharapkan pengelolaan hasil data penyeleksian tingkatan pada English Language School (ELS) dapat menjadi lebih baik dari pada system sebelumnya dan dapat disesuaikan dengan tingkatan yang tersedia sesuai dengan kemampuan pendaftar dalam mempelajari bahasa Inggris.

3. Dengan aplikasi website, diharapkan dapat memberikan kemudahan kepada pendaftar yang ingin mendaftar tentang fasilitas dan tingkatan yang tersedia pada English Language School (ELS).

4. Dengan adanya sistem yang baru, diharapkan nantinya akan mempermudah pihak English Language School (ELS) dalam mengelola hasil data penyeleksian dengan cepat dan dapat di informasikan secara lansung kepada pendaftar dan diharapkan dapat membantu mempermudah pihak English Language School (ELS) dalam mengelola laporan hasil data penyeleksian

\section{LANDASAN TEORI}

\subsection{Pengertian Sistem}

Sistem merupakan kumpulan objek atau elemen yang saling berinteraksi untuk mencapai satu tujuan. Sistem sebagai suatu jaringan kerja dari prosedur-prosedur yang saling berhubungan, 
berkumpul bersama-sama untuk melakukan suatu kegiatan atau untuk menyelesaikan suatu sasaran tertentu (Lestari dkk, 2017).

Dalam memahami dan mendefenisikan suatu bentuk sistemterdapat dua pendekatan yang dapat dimanfaatkan atau digunakan untuk menerangkannya (Ramadhanu, 2017),yaitu sebagai berikut:

1. Pendekatan prosedur Sistem adalah kumpulan dari prosedur-prosedur yang saling berkaitan antara satu dengan yang lainnya serta mempunyai suatu maksud atau tujuan tertentu.

2. Pendekatan yang menekankan pada komponen Sistem adalah kumpulan dari komponen yang saling berhubungan atau berkaitan antara satu dengan yang lainnya membentuk satu kesatuan untuk mencapai tujuan tertentu.

\subsection{Pengertian Sistem Informasi}

Sistem informasi adalah suatu sistem di dalam suatu organisasi yang mempertemukan kebutuhan pengolahan transaksi harian yang mendukung fungsi operasi organisasi yang bersifat manajerial dengan kegiatan strategi dari suatu organisasi untuk dapat menyediakan kepada pihak luar tertentu dengan laporan-laporan yang diperlukan (Khairullah dkk, 2017).

\subsection{Alat Bantu Perancangan Sistem}

UML (Unified Modeling Language) adalah perangkat lunak yang berparadigma "berorientasi objek". Pemodelan (modeling) sesungguhnya digunakan untuk penyederhanaan permasalahan-permasalahan yang kompleks sedemikian rupa sehingga lebih mudah dipelajari dan dipahami. Penggunaan model ini bertujuan untuk mengidentifikasikan bagian-bagian yang termasuk dalam lingkup sistem yang dibahas dan bagaimana hubungan antara sistem dengan subsistem maupun system lain diluarnya (Maimunah dkk, 2017).

\section{Use Case Diagram}

2. Class Diagram

3. Activity Diagram

4. Sequence Diagram

5. Deployment Diagram

\section{ANALISA DAN PERANCANGAN}

Analisa sistem dapat didefenisikan sebagai penguraian dari suatu sistem yang utuh kedalam bagianbagian komponennya dengan maksud untuk mengidentifikasi dan mengevaluasi permasalahan-permasalahan, kesempatan-kesempatan, hambatan-hambatan yang terjadi dan kebutuhan-kebutuhan yang diharapkan sehingga dapat diusulkan perbaikan-perbaikannya (Ramadhanu, 2018).

\subsection{Analisa Sistem yang Sedang Berjalan}

Sistem pendaftaran dan seleksi pemilihan tingkatan pada ELS Padang saat ini masih menggunakan cara manual dan tanpa di tunjang dengan teknologi komputer sehingga butuh waktu yang lama dan keterbatasan informasi dapat menyulitkan pendaftar. Pendaftar terlebih dahulu datang ke ELS padang untuk mendapatkan informasi pendaftaran. Selanjutnya dilakukan pencatatan data pendaftar serta test untuk pemilihan kelas atau tingkatan pendaftar.

\subsection{Sistem yang dibangun}

Sistem yang di bangun dari analisa dan solusi terhadap sistem yang lama adalah sebagai berikut: 
1. Informasi mengenai pendaftaran dan promosi yang ada pada ELS Padang.

2. Pendaftar terlebih dahulu secara online mendaftar untuk mengerjakan test atau seleksi tingkatan.

3. Proses pendaftaran dapat dilakukan melalui Website.

4. Bukti pendaftaran dan hasil seleksi dapat dicetak melalui Website, untuk selanjutnya melakukan konfirmasi pembayaran.

\subsection{Perancangan Sistem Informasi}

Perancangan sistem dapat dirancang dalam bentuk bagan alir sistem (system flowchart), yang merupakan alat bentuk grafik yang dapat digunakan untuk menunjukan urutan-urutan proses dari sistem (Ramadhanu dkk, 2019)

\subsubsection{Unified Modelling Language (UML)}

Perancangan sistem dilakukan dengan menggunakan beberapa metode dalam pembuatan sistem, yaitu sebagai berikut:

\subsubsection{Use Case Diagram}

Berikut adalah use case diagram pada sistem pendaftaran dan penyeleksian tingkatan pada ELS Padang, dapat dilihat pada Gambar 3.1 :

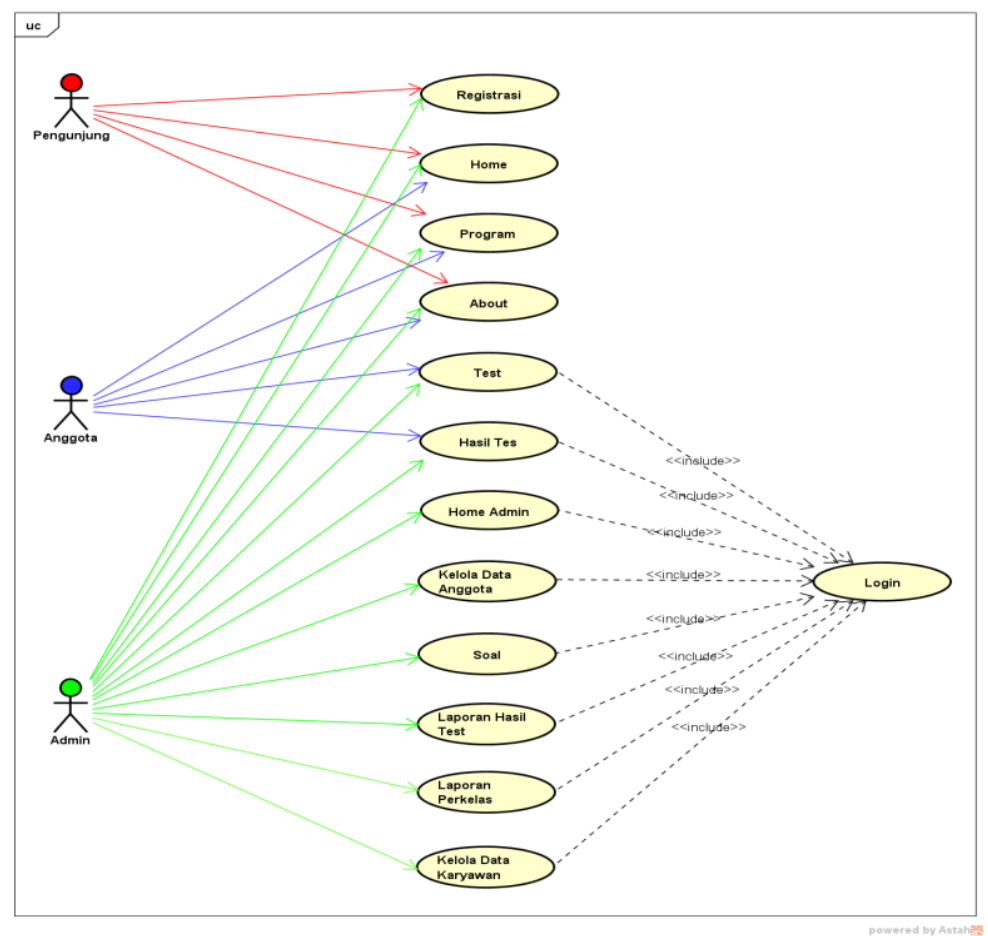

Gambar 3.1 USD Sistem yang dibuat

\section{Keterangan :}

1. Pengunjung dapat melihat halaman Home, Tentang Kami, Program, Event dan Registrasi untuk mendaftar sebagai pelajar. 
2. Pengunjung yang telah mendaftar dan login atau pelajar dapat melakukan Tes Seleksi untuk mengetahui pada kelas atau tinggkatan mana yang akan dimasuki sesuai dengan kemampuan pelajar tersebut.

3. Admin dapat melakukan pengelolaan slide images pada home, data Program, data tentang kami, melihat daftar pendaftar serta mencetak laporan pendaftar.

\subsubsection{Class Diagram}

Class diagram adalah sebuah spesifikasi yang jika diinstansiasi akan menghasilkan sebuah objek dan merupakan inti dari pengembangan dan perancangan berorientasi objek. adapun interaksinya dapat dilihat pada Gambar 3.2 :

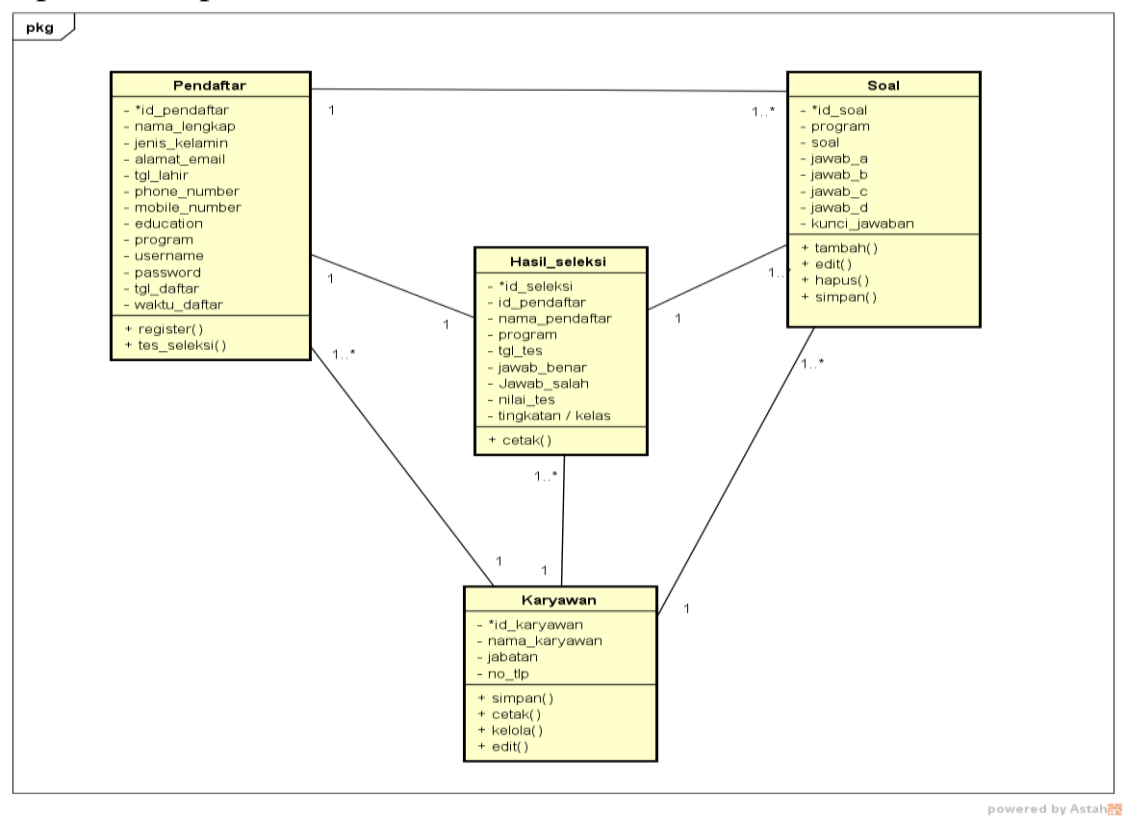

Gambar 3.2 CD Sistem yang dibuat

\subsubsection{Acivity Diagram System}

Activity diagram system pada sistem pendaftaran dan seleksi tingkatan pada English Languae School (ELS) Padang, adalah sebagai berikut :

1. Activity Diagram Pengunjung

Activity Diagram Pengunjung menggambarkan aktivitas pengunjung didalam sistem serta memilih aktivitas dengan menu-menu pilihan yang ada, yang digambarkan seperti Gambar 3.3 : 


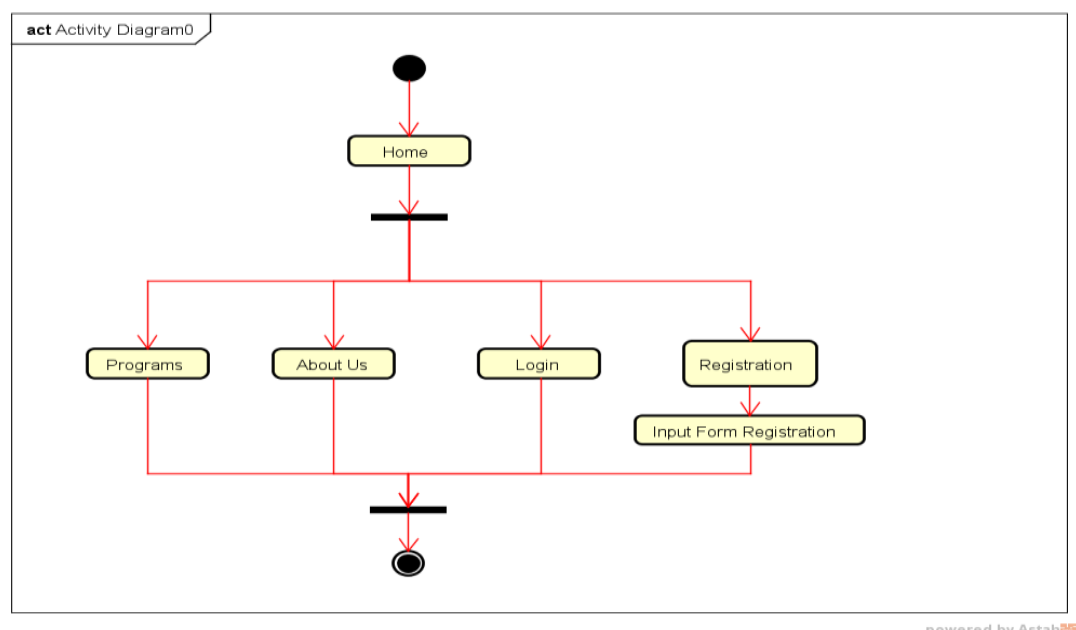

Gambar 3.3 AD Pengunjung

2. Activity Diagram Pendaftar

Activity Diagram Pendaftar menggambarkan aktifitas pendaftar terhadap sistem, melakukan aktivitas yang memerlukan validasi data dengan login, serta mendaftar, yang digambarkan seperti gambar 3.4 :

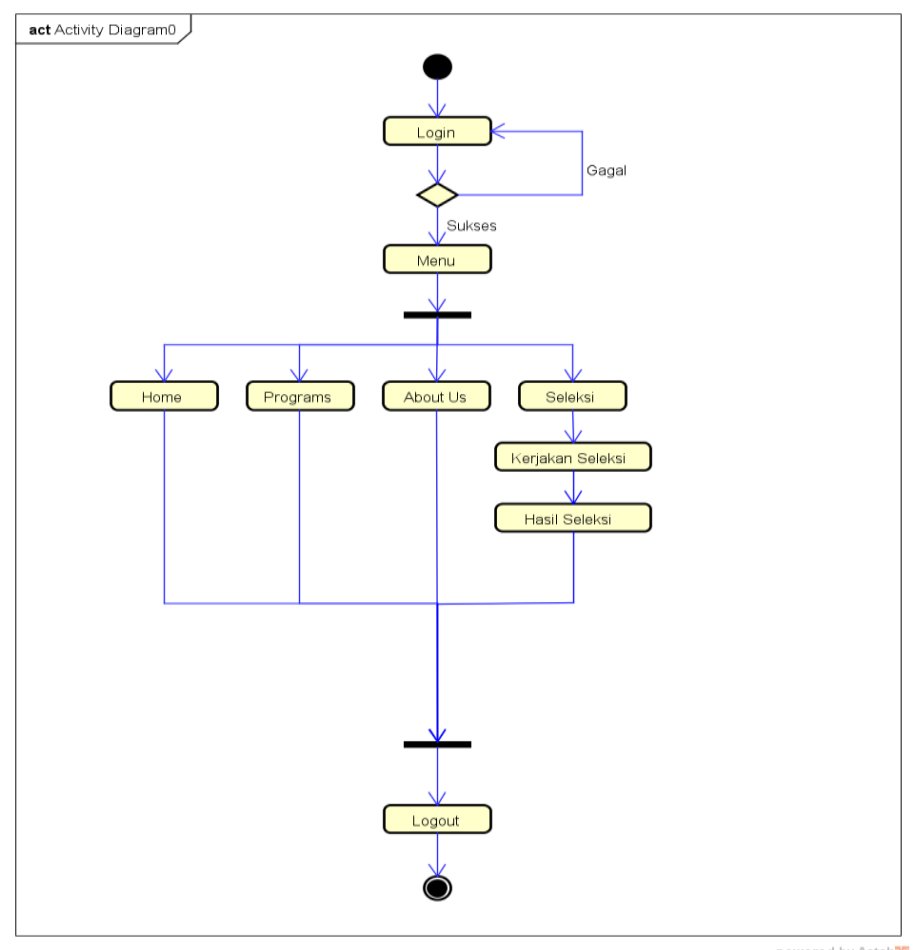

\section{Gambar 3.4 AD Anggota}

3. Activity Diagram Admin

Activity diagram Admin menggambarkan pelanggan terhadap sistem, yang digambarkan seperti gambar 3.5 : 


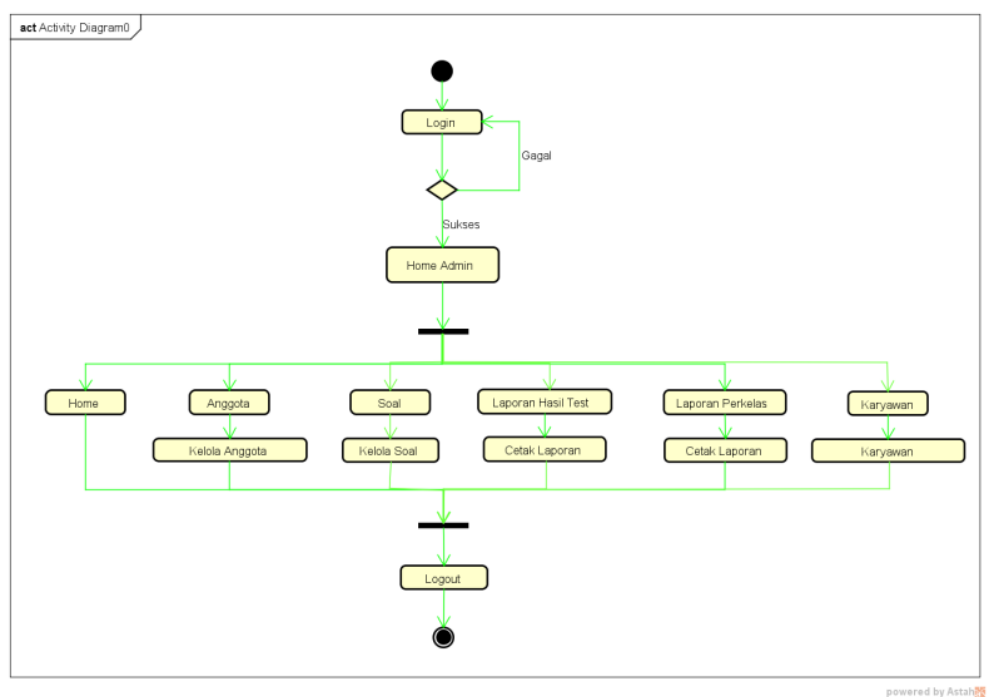

\subsubsection{Sequence Diagram System}

\section{Gambar 3.5 AD Admin}

Sequence diagram system menggambarkan hubungan antara sejumlah objek dalam urutan waktu. Sequence diagram yang ada dalam sistem informasi yang dibuat dapat dilihat sebagai berikut :

\section{Sequence Diagram Pendaftar}

Sequence Diagram Pendaftar mengambarkan hubungan para pendaftar di dalam sistem. Hubungan pendaftar dengan Menu login sebagai validasi sebelum mengakses menu dan halaman yang lainnya. Sehingga setelah dilakukan validasi maka pendaftar dapat melakukan penyeleksian pemillihan tinggkat dengan menjawab soal yang akan diberikan dengan waktu yang telah ditetapkan dan melihat hasil seleksi yang telah dikerjakan, yang digambarkan seperti Gambar 3.6 :

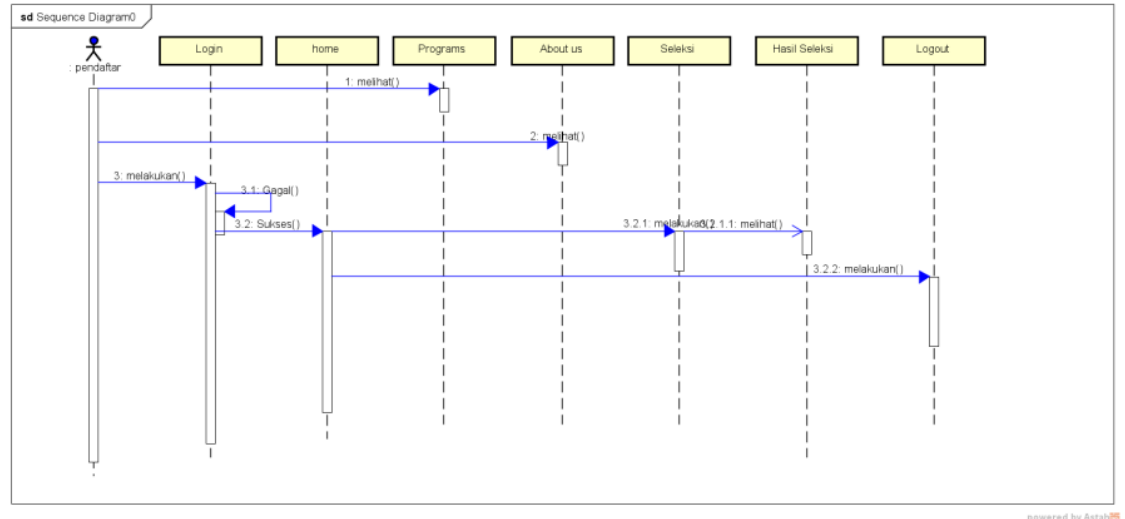

Gambar 3.6 Sequence Diagram Pendaftar

2. Sequence Diagram Admin

Sequence diagram Admin mengambarkan hubungan akses pada admin di dalam sistem. Setelah melakukan login, admin dapat mengelola halaman Home, Registration, Programs, Events, About Us, Seleksi dan Laporan Pendaftar yang digambarkan seperti Gambar 3.7 : 


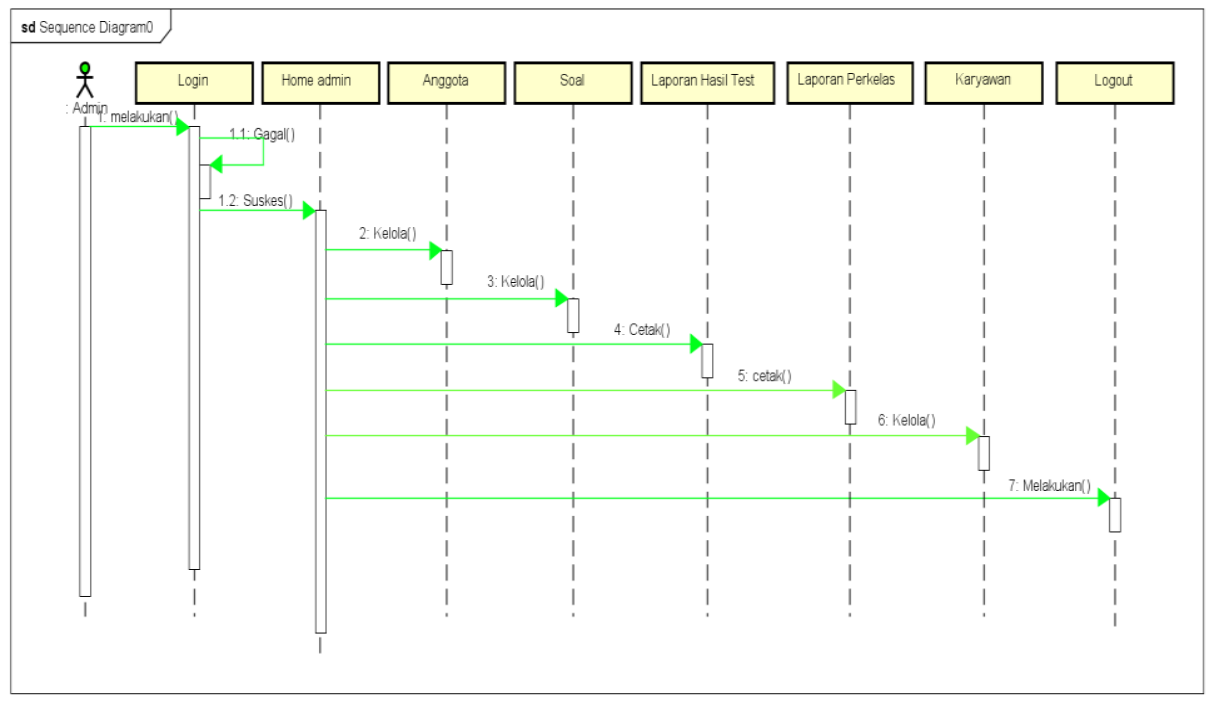

Gambar 3.7 Sequence Diagram Admin

3. Sequence Diagram Pengunjung

Sequence diagram Pengunjung mengambarkan hubungan pengujung di dalam sistem. Pengunjung dapat melihat Menu dan halaman yang terdiri dari Home, Programs, Events, Registration dan About Us yang digambarkan seperti Gambar 3.8 :

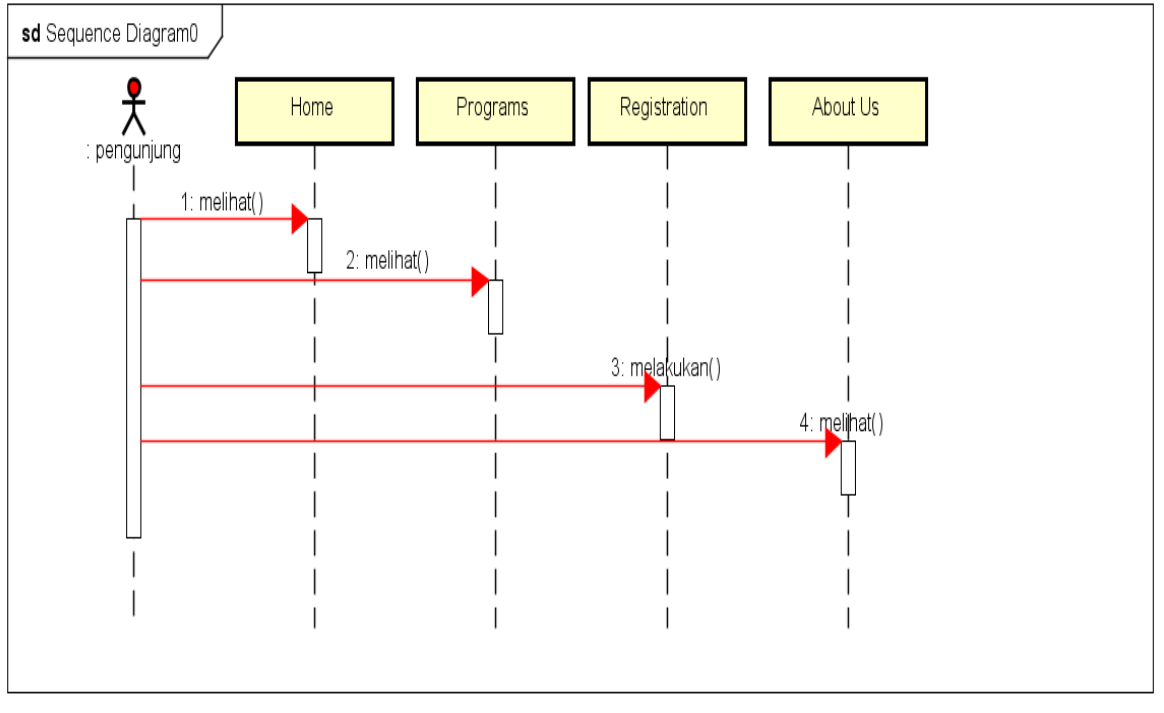

Gambar 3.8 Sequence Diagram Pengunjung

\subsubsection{Deployment Diagram}

Diagram Deployment Peta pada sebuah sistem secara fisik. Diagram ini akan melihatkan bagian-bagian software yang berjalan pada bagian-bagian hardware yang digunakan untuk mengimplementasikan sebuah sistem dan keterhubungan terhadap hardware tersebut. yang digambarkan seperti Gambar 3.9 : 


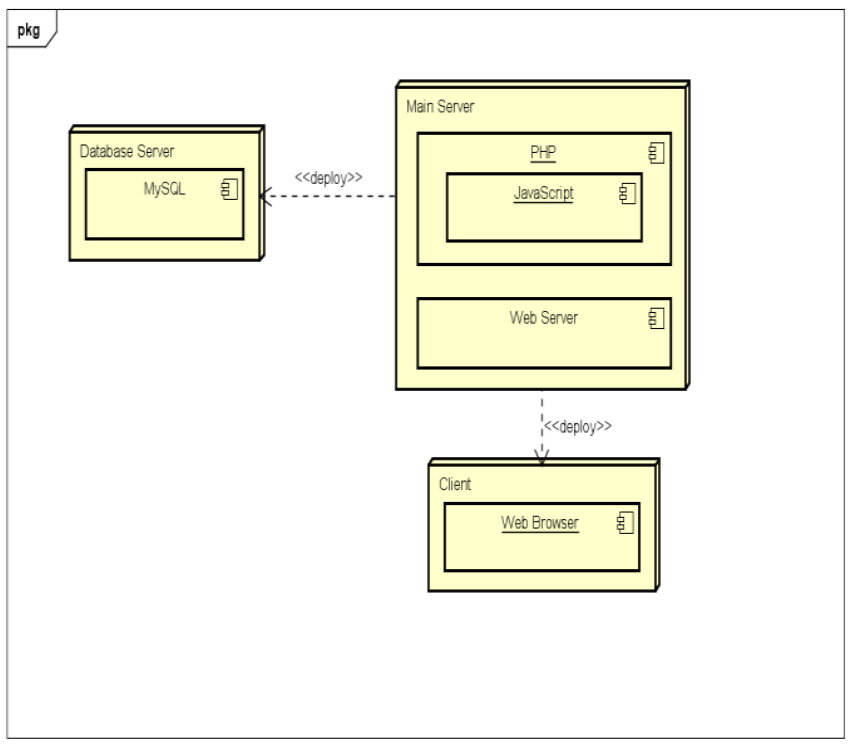

Gambar 3.9 Deployment Diagram

\section{TESTING DAN IMPLEMENTASI SISTEM}

\subsection{Tampilan Menu Halaman Pertama}

Menu halaman utama menampilkan bentuk halaman website yang dapat diakses pengunjung dan anggota mengakses halaman web dan terdapat menu-menu yang bisa diakses adapun tampilannya seperti pada Gambar 4.1 :
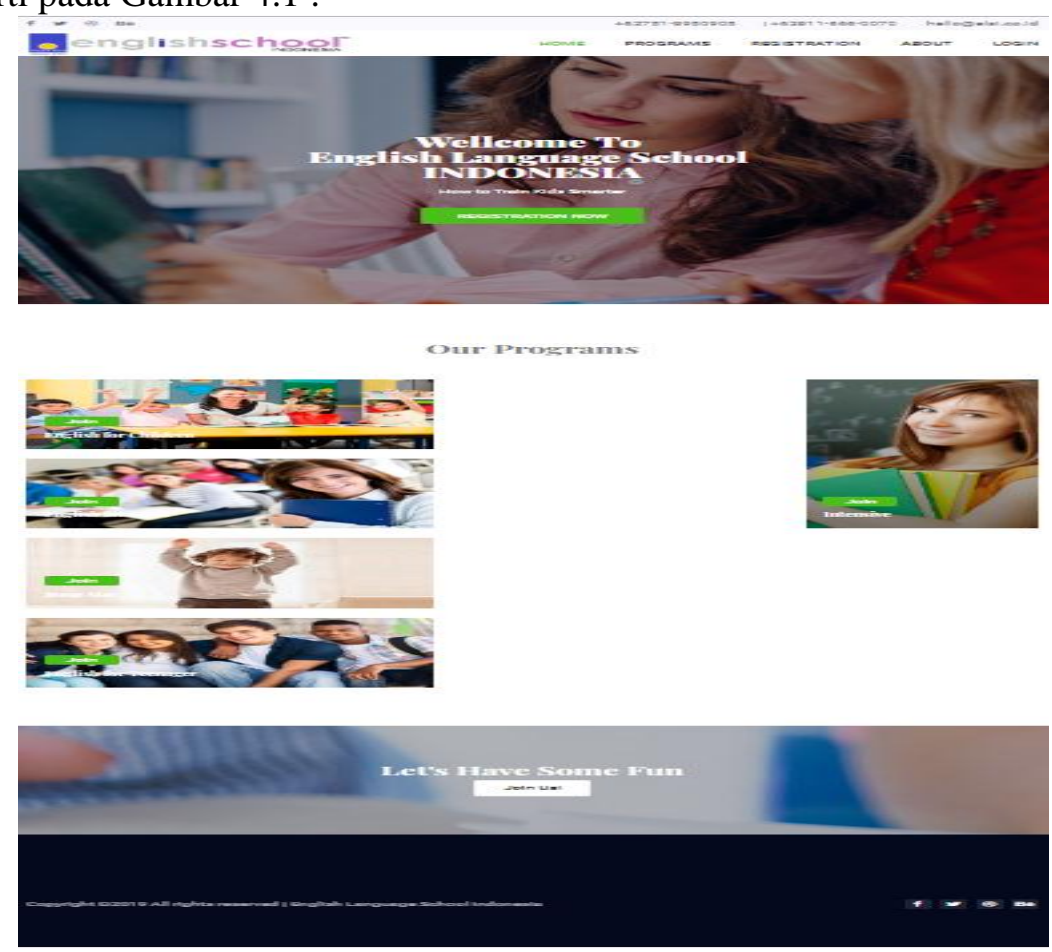

Gambar 4.1 Halaman Utama Website 


\subsection{Halaman Utama Program}

Form ini digunakan untuk menampilkan rincian program yang tersedia pada English Language School (ELS) Padang, seperti pada Gambar 4.2 :
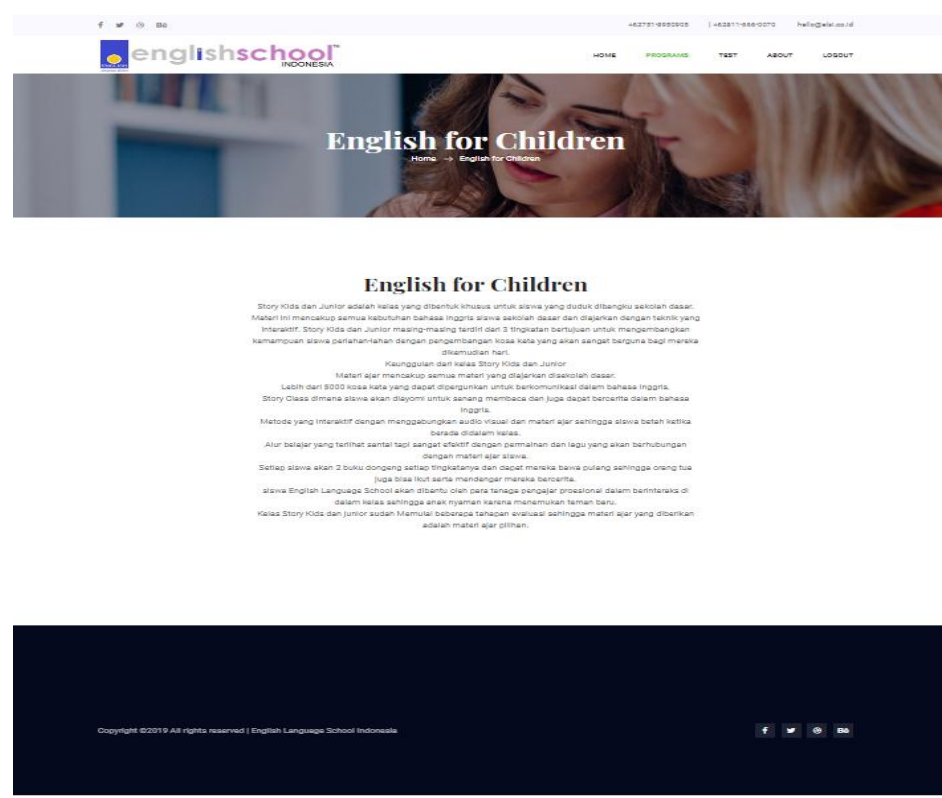

Gambar 4.2 Form Programs

\subsection{Tampilan Halaman Menu Registrasi}

Menu mendaftar digunakan oleh pengunjung yang akan melakukan pendaftaran. Untuk mengakses halaman ini user harus menggunakan menu registration, selanjutnya mendapatkan tampilan halaman form seperti pada Gambar 4.3 :

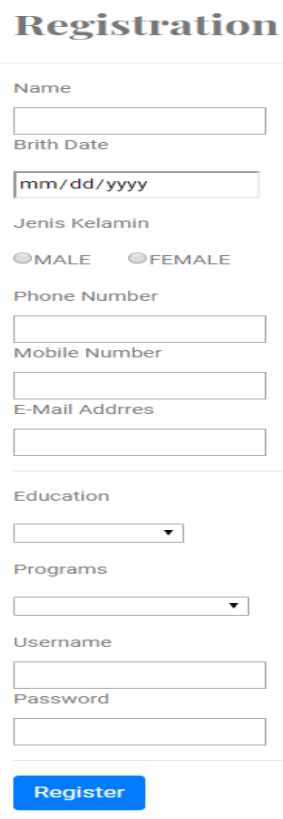

Gambar 4.3 Form Registration

\subsection{Tampilan Halaman Menu Pelanggan}

Jurnal KomtekInfo Vol : 6 No : $1 \| 2019$ 
Form ini digunakan untuk melakukan penyeleksian kepada pendaftar sesuai dengan program yang dipilih pada saat melakukan pendaftaran dan kemampuan pendaftar dalam menjawab soal yang diberikan dalam waktu yang telah ditentukan, seperti pada Gambar 4.4 :

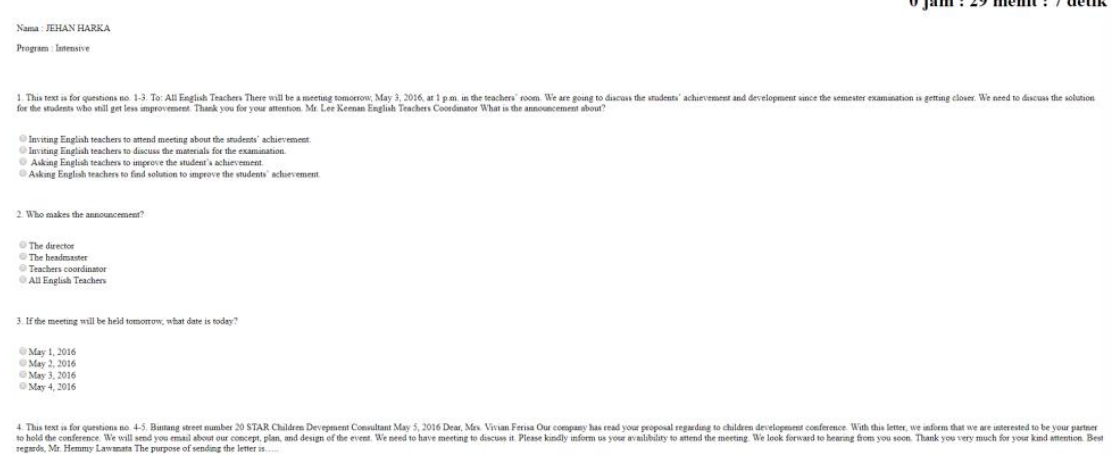

Gambar 4.4 Form Test Programs

Setelah Anggota mengisi soal yang telah disediakan, hasil dari test tersebut akan lansung keluar berserta nilai dan tingkat kelas yang didapat dari hasil test tersebut, seperti pada Gambar 4.5:

\begin{tabular}{|c|c|c|}
\hline \multicolumn{3}{|c|}{ 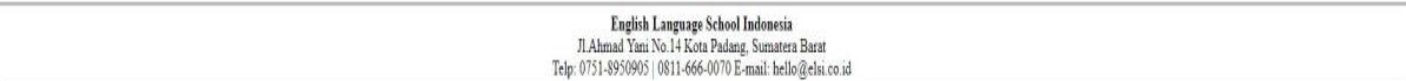 } \\
\hline \multicolumn{3}{|l|}{ CONGRATULATION } \\
\hline \multicolumn{3}{|c|}{ Selamat Anda telahl Nelakkukan Test Seleksi dan anda Berhasil masulk menjadi pelajar di ENGLISH LANGLAGE SCHOOL INDONESLA (ELS) dengan tungkatan sebagai berikut } \\
\hline Nama & : & \\
\hline Hasil seaksi & $:$ & \\
\hline Tangal Seleksi & $:$ & \\
\hline Progem & : & \\
\hline Mnglat Kelas & : & \\
\hline \multicolumn{3}{|c|}{ Silahkan Cetakk Hasil Seleks ini untuk dibara dan melakukan koffirmasi pembayaran dan jadral kelas pada kantor ENGLISH LAVGVAGE SCHOOL INDONEISA (ELST). } \\
\hline & & 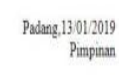 \\
\hline Brandic & & (Elinuth \\
\hline
\end{tabular}

\section{Gambar 4.5 Form Hasil Test Programs}

Pendaftar dapat mencetak hasil test tersebut sebagai bukti telah melakukan test untuk kemudian di bawa pada saat konfirmasi pendaftaran pada kantor English Language School (ELS) Padang, seperti pada Gambar 4.6: 


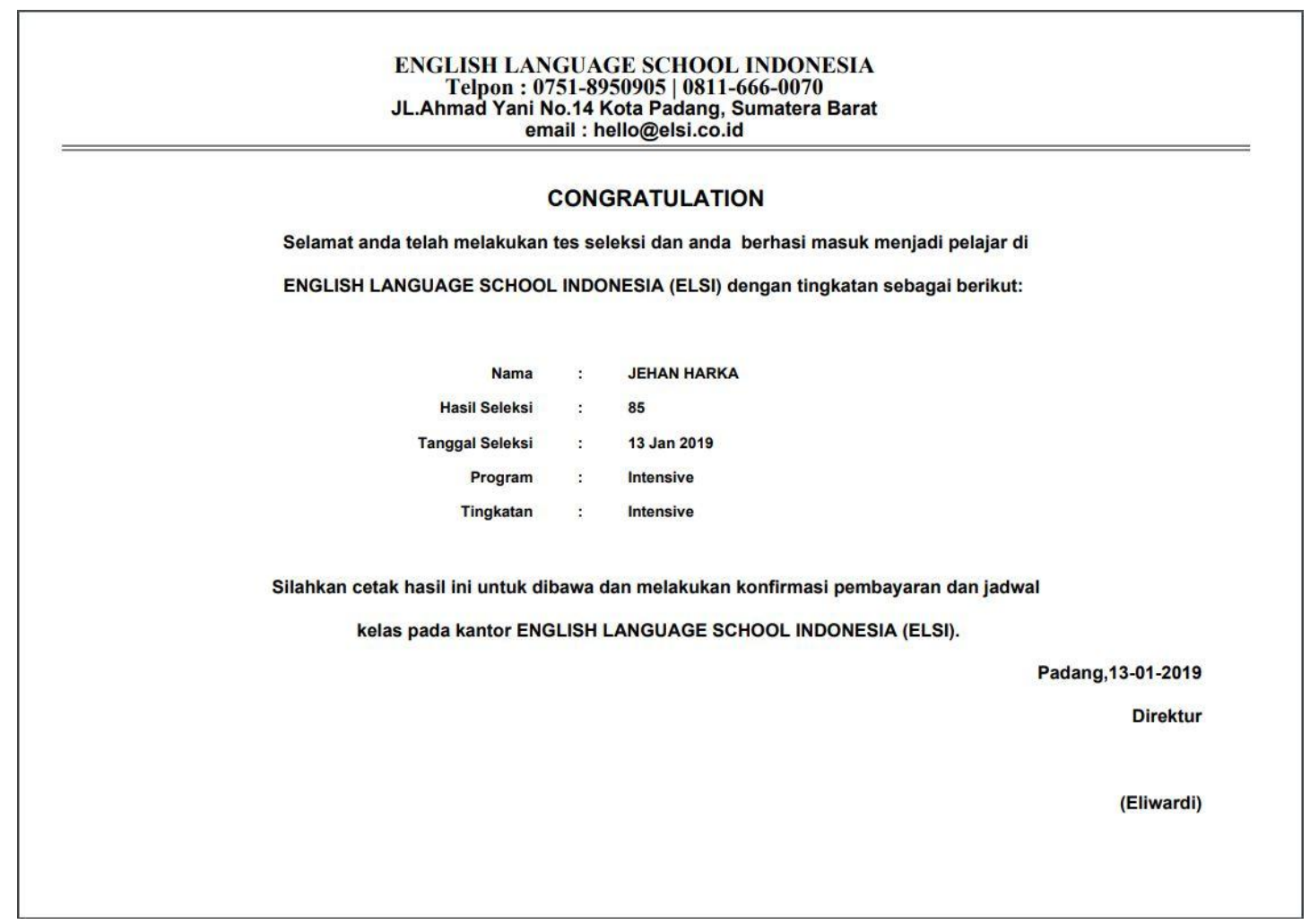

\section{Gambar 4.6 Laporan Hasil Test}

\subsection{Tampilan Utama Admin}

Sebelum masuk ke menu halaman admin, dilakukan login ke sistem dengan mengisi username dan password, adapun tampilan halaman login admin seperti pada Gambar 4.7 :

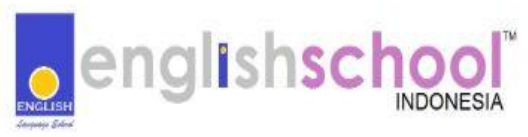

\section{Please Login Administrator}

1 Username

- Password

Gambar 4.7 Tampilan Halaman Login Admin 
Setelah login admin dibawa pada halaman admin, dimana admin dapat mengelola web terutama dalam proses pemesanan dan memberikan laporan pemesanan, untuk tampilan seperti pada Gambar 4.8 :
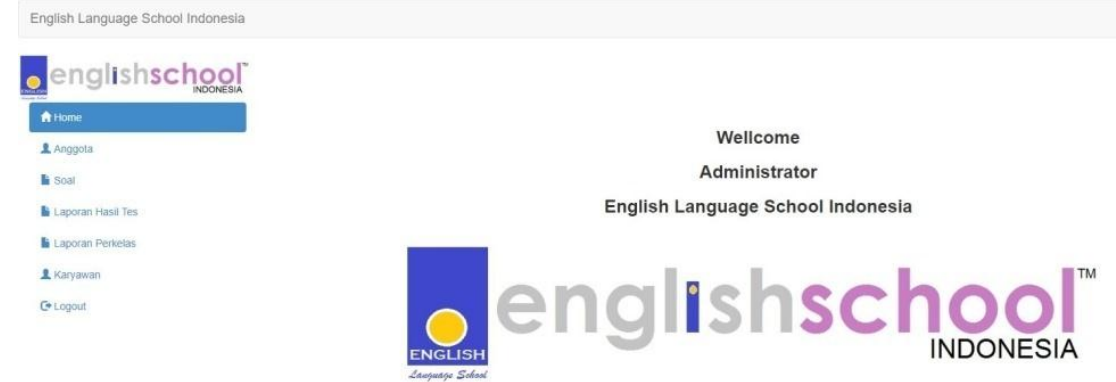

\section{Gambar 4.8 Tampilan Halaman Admin}

\subsection{Tampilan Laporan Perbulan}

Laporan pendaftaran perbulan berisi data pendaftar atau anggota English Language School (ELS) Padang yang di inputkan oleh admin ke sistem berdasarkan bulan. Untuk menampilkan form laporan data pendaftaran perbulan, admin harus memilih bulan yang akan dicetak, lalu mengklik tombol lihat untuk memastikan isi data laporan dan mengklik cetak laporan perbulan, bentuk tampilan laporan pendaftaran perbulan seperti Gambar 4.9 :

ENGLISH LANGUAGE SCHOOL INDONESIA
$\begin{aligned} & \text { Telpon : } 0751-8950905 \text { | 0811-666-0070 } \\
& \text { JL.Ahmad Yani No.14 Kota Padang, Sumatera Barat } \\
& \text { email : hello@elsi.co.id }\end{aligned}$
Laporan Perbulan Pendaftaran dan Hasil Seleksi
Bulan : $\mathbf{0 1}$ - 2019
\begin{tabular}{|c|c|c|c|c|c|}
\hline No & Nama Pendaftar & Program & Tanggal Seleksi & Nilai Seleksi & Kelas \\
\hline 1 & JEHAN HARKA & Intensive & $2019-01-11$ & 15 & Intensive \\
\hline 2 & NECHEA SINTIA RAHMAT & Intensive & $2019-01-11$ & 15 & Intensive \\
\hline 3 & HELYANA YOSEPA & English for Adult & $2019-01-11$ & 30 & Adult-1 \\
\hline 4 & DWI & English for Teenager & $2019-01-12$ & 90 & Block Buster-3 \\
\hline 5 & ANANTO & English for Teenager & $2019-01-12$ & 100 & Block Buster-3 \\
\hline 6 & REFORMA & English for Teenager & $2019-01-12$ & 100 & Block Buster-3 \\
\hline 7 & SETIANA & English for Teenager & $2019-01-12$ & 75 & Block Buster-2 \\
\hline 8 & MEISSY & English for Teenager & $2019-01-12$ & 75 & Block Buster-2 \\
\hline 9 & ANGGUN & English for Teenager & $2019-01-12$ & 75 & Block Buster-2 \\
\hline 10 & AZZAHARANI & English for Teenager & $2019-01-12$ & 75 & Block Buster-2 \\
\hline 11 & SALSABILA & English for Teenager & $2019-01-12$ & 75 & Block Buster-2 \\
\hline 12 & RANGGA & English for Teenager & $2019-01-12$ & 100 & Block Buster-3 \\
\hline 13 & MAULIDINA & Jump Star & $2019-01-12$ & 5 & Jump Star-1 \\
\hline
\end{tabular}

\section{Gambar 4.9 Laporan Pendaftaran dan Hasil Seleksi Perbulan}




\subsection{Tampilan Laporan Pertahun}

Laporan pendaftaran pertahun berisi data pendaftar atau anggota English Language School (ELS) Padang yang di inputkan oleh admin ke sistem berdasarkan tahun. Untuk menampilkan form laporan data pendaftaran pertahun, admin harus memilih tahun yang akan dicetak, lalu mengklik tombol lihat untuk memastikan isi data laporan dan mengklik cetak laporan pertahun, bentuk tampilan laporan pendaftaran pertahun seperti Gambar 4.10 :

\begin{tabular}{|c|c|c|c|c|c|}
\hline \multicolumn{6}{|c|}{$\begin{array}{l}\text { Laporan Pertahun Pendaftaran dan Hasil Seleksi } \\
\qquad \text { Tahun : } 2019\end{array}$} \\
\hline No & Nama Pendaftar & Program & Tanggal Seleksi & Nilai Seleksi & Kelas \\
\hline 1 & JEHAN HARKA & Intensive & 2019-01-11 & 15 & Intensive \\
\hline 2 & NECHEA SINTIA RAHMAT & Intensive & 2019-01-11 & 15 & Intensive \\
\hline 3 & HELYANA YOSEPA & English for Adult & 2019-01-11 & 30 & Adult-1 \\
\hline 4 & DHIYA & Jump Star & 2019-01-12 & 100 & Jump Star-3 \\
\hline 5 & DWI & English for Teenager & 2019-01-12 & 90 & Block Buster-3 \\
\hline 6 & ANANTO & English for Teenager & 2019-01-12 & 100 & Block Buster-3 \\
\hline 7 & REFORMA & English for Teenager & 2019-01-12 & 100 & Block Buster-3 \\
\hline 8 & SETIANA & English for Teenager & 2019-01-12 & 75 & Block Buster-2 \\
\hline 9 & MEISSY & English for Teenager & 2019-01-12 & 75 & Block Buster-2 \\
\hline 10 & ANGGUN & English for Teenager & 2019-01-12 & 75 & Block Buster-2 \\
\hline 11 & AZZAHARANI & English for Teenager & 2019-01-12 & 75 & Block Buster-2 \\
\hline 12 & SALSABILA & English for Teenager & 2019-01-12 & 75 & Block Buster-2 \\
\hline 13 & RANGGA & English for Teenager & 2019-01-12 & 100 & Block Buster-3 \\
\hline
\end{tabular}

\section{Gambar 4.10 Laporan Pendaftaran dan Hasil Seleksi Pertahun}

\subsection{Tampilan Laporan Perkelas}

Laporan perkelas berisi data pendaftar atau anggota English Language School (ELS) Padang yang di inputkan oleh admin ke sistem berdasarkan kelas. Untuk menampilkan form laporan data pendaftaran perkelas, admin harus memilih bulan dan kelas yang akan dicetak, lalu mengklik tombol lihat untuk memastikan isi data laporan dan mengklik cetak laporan perkelas, bentuk tampilan laporan perkelas seperti Gambar 4.11 :

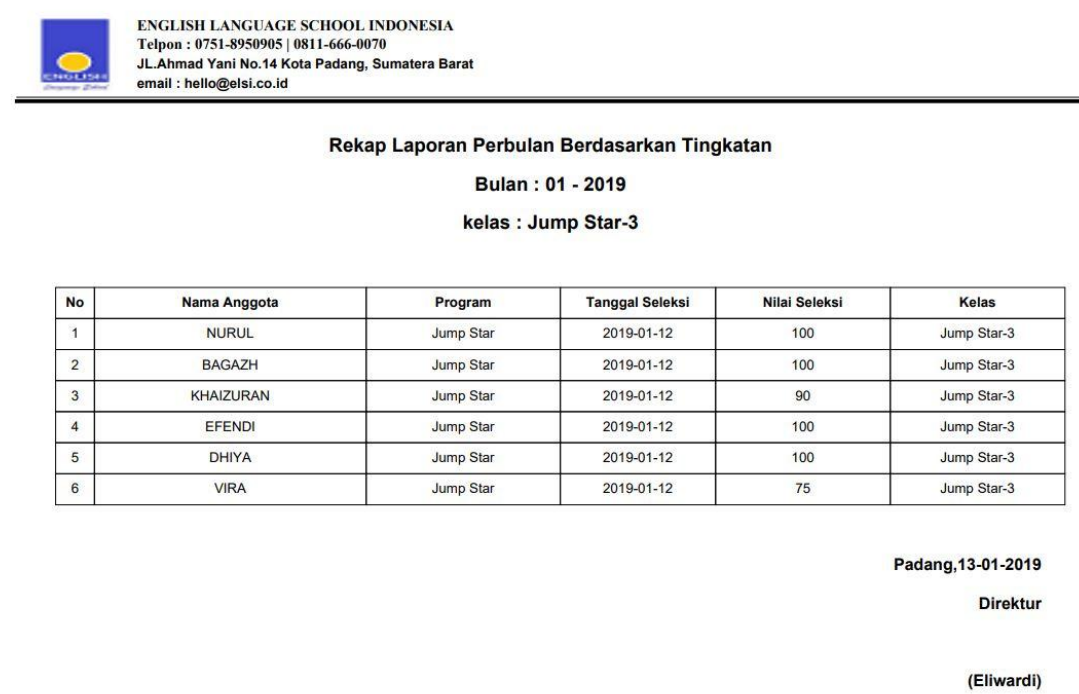

Gambar 4.11 Laporan Pendaftaran dan Hasil Seleksi Perkelas 


\section{KESIMPULAN DAN SARAN}

\subsection{Kesimpulan}

Berdasarkan pembahasan dan analisa yang telah ditulis pada halaman-halaman sebelumnya, maka penulis dapat menarik kesimpulan sebagai berikut :

1. Dengan diterapkan sistem informasi pendaftaran dan penyeleksian tingkat berbasis website dapat membantu pihak English Language School (ELS) Padang dalam mengelola data pendaftar dengan baik.

2. Perancangan website pendaftaran dan penyeleksian tingkat berbasis website dapat membantu pihak English Language School (ELS) Padang dalam menentukan tingkatan yang tersedia dengan kemampuan pendaftar berdasarkan nilai yang telah didapat pada saat melakukan seleksi online.

3. Perancangan website pendaftaran dan penyeleksian tingkatan sebagai media promosi pada English Language School (ELS) Padang dalam menginformasikan fasilitas dan program yang tersedia pada English Language School (ELS) Padang sesuai dengan kebutuhan para pendaftar.

4. Dengan sistem informasi pendaftaran dan penyeleksian tingkatan berbasis website membantu pihak English Language School (ELS) Padang dalam menyeleksi dan mengolah hasil pendaftar yang telah terdaftar pada sistem.

5. Perancangan sistem informasi pendaftaran dan penyeleksian tingkatan berbasis website membantu pihak English Language School (ELS) Padang dalam merekap laporan pendaftar dan laporan hasil seleksi serta laporan perkelas yang telah disediakan.

\subsection{Saran}

Berdasarkan penelitian yang telah dilakukan, maka penulis dapat mengemukakan saran yang berfungasi untuk lebih mengembangkan sistem webbase ini, yaitu adalah sebagai berikut :

1. Admin yang mengelola website diharapkan dapat terus melakukan pengolahan data dan pengawasan data pendaftar pada English Language School (ELS) Padang.

2. Memberikan pelatihan seperlunya kepada admin dan pengguna lainnya yang akan menggunakan sistem agar dapat memberikan hasil yang baik.

3. Sistem yang direncang penulis hanya sebatas website pendaftaran dan penyeleksian tingkatan dan sebagai media promosi pada English Language School (ELS) Padang, sehingga diharapkan adanya pengembangan sistem yang lebih baik lagi.

\section{Referensi}

[1] Lestari, Tutik., Setiawan, Agustinus Eko., \& Prasetiawan, Heru. (2017). Perancangan Sistem Informasi Scheduling SIT (System Integration Test) Berbasis WEB Pada PT. Collega Inti Pratama. Jurnal TAM (Technology Acceptance Model), Vol. 8.

[2] Khairullah., Soedijono, Bambang., \& Fatta, Hanif Al. (2017). Pengukuran Kualitas Sistem Informasi Inventaris Aset Universitas Muhammadiyah Bengkulu Menggunakan Metode MCCALL. Jurnal Informasi Interaktif, Vol. 2

[3] Maimunah., Supriyanti, Dedeh., \& Hendrian. (2017). Aplikasi Sistem Order Online Berbasis Mobile Android Pada Outlet Pizza Hut Delivery. Seminar Nasional Teknologi Informasi Dan Multimedia.

[4] Ramadhanu, agung. (2017). Perancangan Sistem Informasi Penjualan Dan Pendistribusian Bibit Benih Ikan Pada Bbi (Balai Benih Ikan) Perikanan 
Agung Ramadhanu ${ }^{1,}$ Firna Yenila ${ }^{2}$, Rahmatul Husna Arsyah ${ }^{3}$,Andry Novrianto ${ }^{4}$, Jehan Harka ${ }^{5}$

Limapuluh Kota Secara Online Menggunakan Bahasa Pemograman Php Dan Database Mysql. Jurnal KomTekInfo Vol. 4, No. 1, Juni 2017, Hal. 1-8.

[5] Ramadhanu, agung., Rahmatul Husnah Arsyah., Neni Sri wahyuni Nengsi., Nurhaliza. (2017).

Rancang Bangun Aplikasi Mobile Edukasi Mengenai Parenting Skills Bagi

Orang Tua Berbasis Android Dengan Menggunakan Bahasa Pemrograman Java Android. Jurnal Teknologi Dan Sistem Informasi Bisnis, Vol. 1 No. 1 Januari 2019.

[6] Ramadhanu, agung. (2018). Implementasi Aplikasi Mobile Magazine (E-Magazine)

Dengan Menggunakan Bahasa Pemrograman Android Tentang Rekomendasi Tempat Wisata Kuliner Di Kota Padang. Jurnal KomTekInfo Vol. 5, No. 1, Juni 2018, Hal. 35-46. 